\title{
AGRITOURISM IN ITALY AND THE LOCAL IMPACT REFERRING TO ITRIA VALLEY. THE ORGANIC FIRM "RAGGIO VERDE" AND ITS ECOLOGICAL AGRITOURISM PROJECT
}

\author{
Margherita Ciervo ${ }^{1}$
}

Received 20 November 2012; Accepted 20 September 2013

\begin{abstract}
The aim of this article, using a paradigmatic approach, is to understand the evolution of agritouristic activity in Italy, to evaluate the possible local impacts referring to Itria Valley and considering the case of study of the organic firm "Raggio Verde" in Cisternino (Brindisi, Italy) with its project of multifunctional initiatives through the creation of an organic ecological agritourism. The thesis supported is that the local impact of the agritouristic activity is different according to the reference's paradigm (market liberalism or ecological-territorial) and to the agritourism model (with reference to environmental and social relations, and to the dependence's level from external sources). The methodology is inductive, based on qualitative and quantitative analysis, on indirect, direct and participant observation by a research on the field.
\end{abstract}

Key words: agritourism, local impact, commercial agritourism, ecological agritourism, Italy.

Sintesi: L'obiettivo di questo contributo, sulla base di un approccio paradigmatico, è quello di comprendere l'evoluzione dell'attività agrituristica in Italia, per valutare i possibili impatti locali con riferimento alla Valle d'Itria e considerando il caso di studio dell'azienda biologica "Raggio Verde" di Cisternino (Brindisi, Italia) e il suo progetto di apertura alla multifunzionalità attraverso la creazione di un agriturismo bioecologico. La tesi sostenuta è che l'impatto locale dell'attività agrituristica varia a seconda del paradigma di riferimento (liberalismo di mercato o ecologicoterritoriale) e al modello di agriturismo (con riferimento alle relazioni ambientali e sociali, e a livello di dipendenza dalle fonti esterne). La metodologia è induttiva, basata sull'analisi qualitativa e quantitativa, oltre che sull'osservazione indiretta, diretta e partecipativa (resa possibile dalla ricerca sul terreno).

Parole chiave: agriturismo, impatto locale, agriturismo commerciale, agriturismo ecologico, Italia.

\footnotetext{
1 Margerita Ciervo, Assistant Professor of Economic and Political Geography at the Department of Economics, University of Foggia, Via Caggese, 1 - 71100 Foggia (Italy); e-mail: m.ciervo@unifg.it.
} 


\section{Introduction. Theoretical background and methodological approach.}

Agritourism is a kind of rural tourism characterized by a tight connection with agricultural activity, although there are some references also to "agritourism industry" (Tew, Barbieri, 2012; Centner, 2010) and to agritourism as a part of "rural business" (Dougstad, 2008; Kuo, Chiu, 2006). In reality, in literature, there is not a clear definition of agritourism and of the kinds of activities it includes (Dubois Schmitz, 2010), and it can depend on different sociological contexts (ivi, 2011). While there is a debate concerning whether the product is based on a 'working farm' or not, the nature of contact between tourist and agricultural activity, and the degree of authenticity (Philip and others, 2010). As regards this last, referring specifically to the "staged authenticity", the concept was introduced in tourism analysis by MacCannell $(1973,1976)$ using Goffman's (1959) theatrical metaphor and notion of front and back regions, to illustrate the backstage production and promotion as authentic local culture. The staged authenticity is produced by operators in order to create an "appealing package" and satisfy the demand of authenticity from tourists. The risk is that the staged authenticity alters until to destroy the authenticity. These concepts have been developed in several studies (Hughes, 1995; Daniel 1996; Crang, 1997; Waller, Lea, 1999; Edensor, 2000; Olsen 2002; Mkono, 2012) concerning also expressly ecotourism (Kontogeorgopoulos, 2004), heritage tourism (Waitt, 2000; Halewood, Hannam, 2001; Chhabra and others, 2003), culture tourism (Bachleitner, Zins, 1999; Taylor, 2001), rural tourism (Cawalaym, Gillmor, 2002; Sanagustin Fons and others, 2011) and seaside tourism (Sedmak, Mihalic, 2008). Furthermore, some studies rethink and revisit these concepts (Cohen, 1988; Wang, 1999; Reisinger, Steiner, 2006; Hillman, 2007; Hughes, 2009; Zhu, 2012). Basing on the assumption that the demand for authentic experience stems from a search for an authenticity missing in industrialized societies caused by alienation and fragmentation, by processes of commodification and globalization, coupled with the confusion caused by the disappearance of intimacy, creativity, and spontaneity from modern life (MacCannell, 1976), in our research, we use the word authenticity to refer to "the resistances, choices, and commitments that individuals express within the opportunities and constraints provided by globalized markets and global imagery to which international tourism is an increasingly major contributor" (Hughes, 1995, p. 800).

The aims of this paper are: understanding the evolution of agritourist activity in Italy; defining criterion to evaluate local impacts of agritourism referring to Itria Valley (Apulia); considering the case of study of the organic firm "Raggio Verde" in Cisternino with its project of multifunctional initiatives through the creation of an organic ecological agritourism, developed by a research-action.

The approach used is paradigmatic. The thesis supported is that the local impact of the agritourist activity is different according to the reference's paradigm: market liberalism or ecological-territorial. The first one is reductionist and functionalist, and based on a mechanistic and utilitarian vision of nature. It is promoted by European Union (EU) through the Rural Development Program (e.g. LEADER) that has the following objectives: competitiveness, improvement of environment, diversification of economic activities, support to markets and incomes. These aims must be adopted by the States of European Union as prerequisites to get funding access. In the second case, the paradigm is based on a systemic approach and on a not deterministic logic, considering environment and society as parts of a unique autopoietic system that is the result of a "single and unrepeatable combination of social and ecological relations" (Conti, 1996, p. 498). In the first case, agritourism is considered as a possible solution to the agricultural crisis (caused by global competition, suburbanization, rural exodus) and, more generally, to the rural world crisis (Dubois, Schmitz, 2010). However, this agritourism conception is the result both of an "urbanreferential" vision that perceives the countryside as a "mine of resources of raw materials, natural beauty, rest and recreation" (http://ec.europa.eu); and of the competitive logic that has originated the agricultural crisis. For this reason, we can suppose that this kind of agritourism can reproduce similar problems like those that it should solve, including environmental problems (resource's impoverishment, pollution) and socio-economic organization issues (economic dependence, agricultural marginalization). In the second case, agricultural and territorial connection is based on some initiatives promoted by local actors, often aimed at the rural lifestyles and local uses' maintenance, where agritourism is associated with the identity value of 
"being a farmer" (Tew, Barbieri, 2012) and revenues can be used as a way to reach both economic goals and culture aims. It is the case, for instance, of what we call agro-ecotourism (Kuo, Chiu, 2006) or, in Italy, organic ecological agritourism that is based on the mix between organic agriculture and ecotourism, and it cares for ecological balance, biodiversity, respect of local traditional cultures and landscape.

The ecological agritourism project is presented according to the typology framework defined by Philip and others (figure 1) and based on an ideal zero environmental impact closed-loop system.

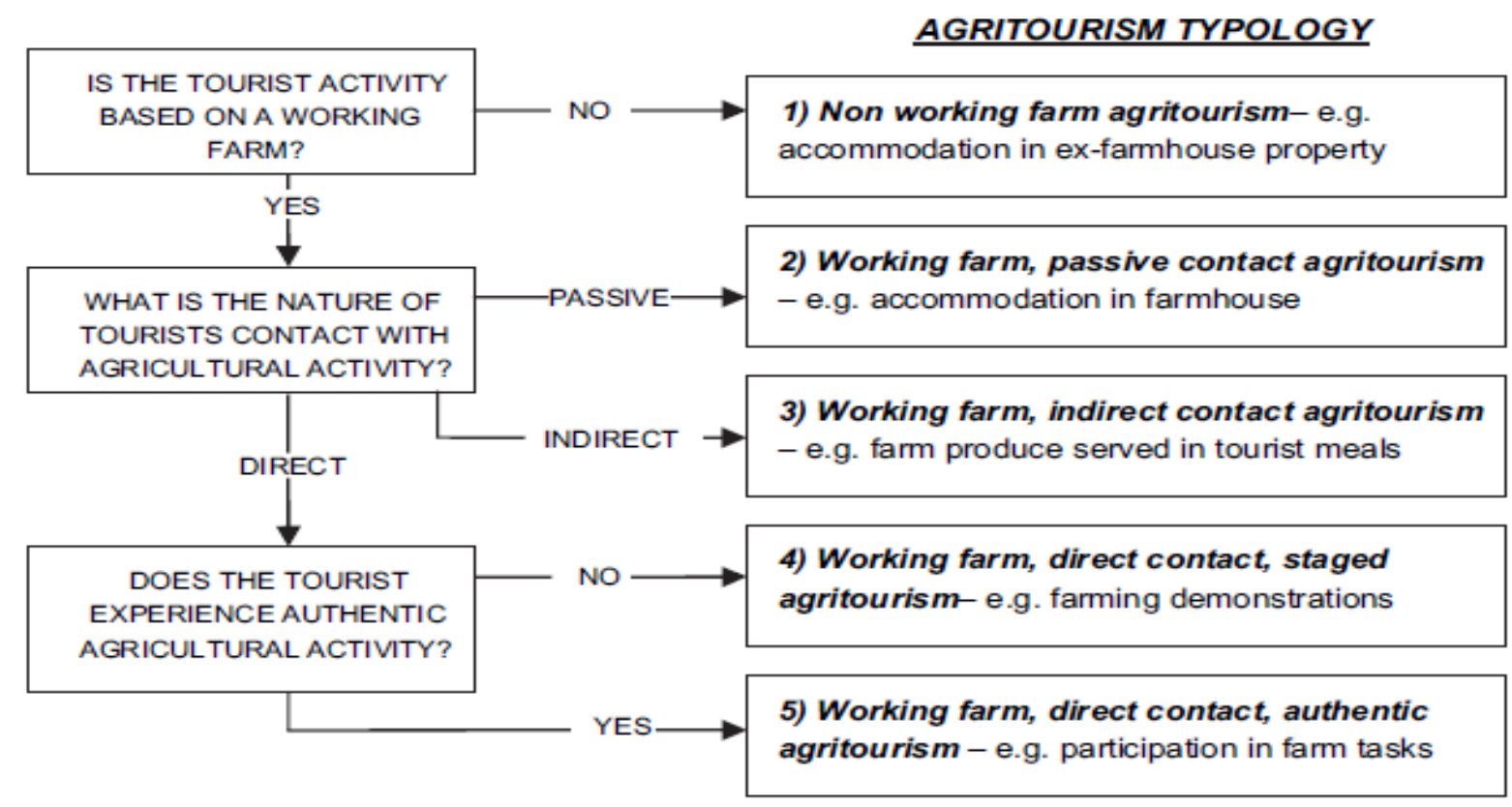

Fig 1. A typology for defining agritourism. Source: Philip and other, 2010, p. 756.

The methodology is essentially inductive, based on a qualitative and quantitative analysis and a multiscalar approach. Specifically, it is grounded on:

a) indirect observation: geographic literature, bibliography, web sites, lows and statistical data, on different levels of spatial scale (European, national, regional and local) concerning organic and social agriculture, rural development, rural tourism and agritourism, environmental protection, solar energy, biofuel, energy saving and black water recovery;

b) direct observation of landscape;

c) participant observation by a research on the field.

This last, referring to the case of study and in order to understand the perception and the mental imagines that lead the enterprise's choices, it has been supported by a subjective evaluation's pattern concerning the main territorial parameters (environment, society, infrastructures, productive and business system, labour market) and several interviews on open demand with the entrepreneur and his family. The interviews on open demand have been made also with the associations cooperating with the firm (AIAB, Italian Organic Agriculture Association; AIPOP, Italian Olive Oil Farmer's Association), associated to the participation to meetings and conferences promoting the "Itria Valley" Local Action Group (LAG). The ecological agritourism project has been realised referring to the firm economic analysis founded on enterprise's literature and official documents; to the SWOT analysis associated to a funding research and to the action research. This last has permitted to work in close collaboration with the entrepreneur and to involve him directly. Particularly, this project has been realised referring to the firm, not as a separate economic subject, but as an integral part of territory to which it is strictly connected by an interdependent bond and through material, water and energy flows. 


\section{Italy: from familiar hospitality towards a commercial agritourism}

In Italy, agritourism was born as a spontaneous hospitality, and then it developed as a tightly connected and complementary activity to the mains activities of cultivation, forestry and breeding (law 730/1987). From 1990, it underwent a gradual and progressive separation from agriculture, becoming in many cases an alternative to it because of a sort of "urbanization" process of services offered according to the urban customs rather than to the rural habits and, on the other hand, because of the management's "corporatization". This last, started by the law 228/2001, has been improved by the law 96/2006, approved in order to harmonise the Italian law to the EU Rural Development Objectives and Programs. In fact, there is the possibility to assign the licence also to agricultural firms formed as commercial societies by capitals or persons, to workers not farmers, or to people not working in the farm for the development of complementary services (law 96/2006). In addition, the law 228/2001 establishes that agritourist activities can be developed also outside the firm, referring as well to sport, touring and horse riding. The progressive separation from agricultural activities and the approach to commercial tourist initiatives are confirmed by the results of an investigation made by INEA (2010), according to it only 33\% of agritourism firms belong to the agricultural sector. In addition, official statistics (ISTAT, 2010) show that, on 19,973 authorised farms of agritourism ${ }^{2}, 57.2 \%$ of these are authorised also to other activities as riding $(1,638)$, touring $(3,190)$, naturalistic watching $(784)$, trekking $(1950)$, mountain bike $(2,800)$, courses $(1,967)$, sport $(4,152)$ and others $(6,312)$. So, the connection with agriculture weakened more and more as agritourism has been co-opted by market system, developmentalist paradigm and competitive $\operatorname{logic}^{3}$, and as it has been introduced among instruments for the economic growth, considered also on a local scale as a solution to the employment and revenue's problems of rural zones.

Therefore, the operative purposes of agritourist firm are:

a) to penetrate the local/national/international market, offering a product according to the demand and, thus, focused on the reasons at the basis of the customers' choices (table 1) that can be considered as a shelter from urban life (Daugstad, 2008) and a "reaction" to the post-modern society (Sharpley, Jepson, 2011; Cawley, Gillmor, 2008);

b) to agree with the needs/desires, even if they are about urban lifestyle rather than the rural one. At this aim, the same marketing's strategies are used (table 2) although, in some cases, these denaturalize the rural life.

In fact if, on the one hand, someone offers solutions that seem an oxymoron (e.g. "charm and luxury agritourism"), joining words like "comfort, refinement, nobility" to words like "countryside, farmer, rural" in a syntactic acrobatics that cannot dissimulate the dissonances:

"The charm agritourism is a luxury agritourism, where the countryside landscape glamour is joined with a familiar welcome [...] with each comfort [...] The charm agritourism has also a high-quality agriculture, able to produce territorial typical specialties with full respect of the most refined traditions, proposing a restoration based on the most astonishing rural cooking recipes, prepared by rare preciousness food raw materials. Also the charm agritourism entertainment activities aim at a high level public, through a kind of organization that, however, is coherent with the noblest rural evidence, the cultural improvement of holiday and the respect of landscape and environment" (www.agriturist.it).

On the other hand, someone proposes the "real agritourism", admitting this way, implicitly, that all the rest is a fake, a representation. It's significant, in this sense, the reference to the "express luxury yet always patinated from the countryside lifestyle" (www.agriturist.it).

\footnotetext{
${ }^{2}$ Agritourist firms registered in 2010 are about a third more than in 2003, and over 65\% than in 2001.

${ }^{3}$ It is emblematic in this sense the Italian name of "Department of quality and rural world competitive policies. General direction of competitiveness for rural development. Agritourism Office".
} 


\begin{tabular}{|l|l|}
\hline Segments & Reasons \\
\hline Well-being & $\begin{array}{l}\text { To relax body and mind; to cut off power from routine and city bedlam; to escape } \\
\text { from frenetic rhythms; to take back own time; to do sport in an ideal place; to have } \\
\text { entertainment, to enjoy quiet and repose, clean air, genuine food. }\end{array}$ \\
\hline Relational & $\begin{array}{l}\text { To live genuine human relationship; to enjoy familiar atmosphere and warm } \\
\text { welcome. }\end{array}$ \\
\hline Nostalgic & $\begin{array}{l}\text { To return to the nature; to recover own roots and the community sense. } \\
\text { and cultural customs, territorial heritage. }\end{array}$ \\
\hline Cultural & $\begin{array}{l}\text { To desire to aid "to protect little farms from progress and market laws", to enjoy } \\
\text { natural beauties. }\end{array}$ \\
\hline Ecologic & $\begin{array}{l}\text { To experiment with the connection between human being and nature; to look for a } \\
\text { spiritual dimension. }\end{array}$ \\
\hline Spiritual & To enjoy the exclusive place; to benefit from the economic prix. \\
\hline
\end{tabular}

Tab 1. Reasons of agritourism choice (by some interviews in Italy) organised by macro segments. Source: own table on data by ISMEA, MPAAF 2011a, 2011b, 2011c; INSART, 2009.

\begin{tabular}{|l|l|l|l|l|l|l|}
\hline $\begin{array}{c}\text { Socio- } \\
\text { economic }\end{array}$ & Localisation & Structure & Functionality & Period & Events & Target \\
\hline Charm & $\begin{array}{l}\text { Natural } \\
\text { reserve }\end{array}$ & Castle & Cultural & Carnival & Marriages & Families \\
\hline Luxury & Country & $\begin{array}{l}\text { Historical } \\
\text { dwelling }\end{array}$ & Natural & Easter & $\begin{array}{l}\text { Religious } \\
\text { celebrations }\end{array}$ & $\begin{array}{l}\text { Young } \\
\text { people }\end{array}$ \\
\hline Comfort & See & Suite & Ecologic & Summer & Receiving & Couples \\
\hline Economic & Mountain & Farm & Relax & Weekend & S. Valentino & $\begin{array}{l}\text { Disabled } \\
\text { people }\end{array}$ \\
\hline Last minute & Hill & $\begin{array}{l}\text { Real } \\
\text { agritourism }\end{array}$ & Entertainment & $\begin{array}{l}\text { National } \\
\text { celebrations }\end{array}$ & $\begin{array}{l}\text { Romantic } \\
\text { escape }\end{array}$ & $\begin{array}{l}\text { People } \\
\text { with pets }\end{array}$ \\
\hline & Lake & & $\begin{array}{l}\text { Mix nature, relax, } \\
\text { entertainment }\end{array}$ & Local feasts & Business & \\
\hline
\end{tabular}

Tab 2. Some examples of agritourist offers, segmented according to different parameters. Source: own table on data by www.agriturist.it.

So, landscape, rural heritage ${ }^{4}$, green, silence, clean air, food quality risk to turn into a mere resource for tourism industry. Cultural, culinary and handcraft traditions risk to be declassed to folklore. Territorial identity risks becoming exclusively a theoretical distinctive identity "considered only for marketing competitive advantage that can assure in comparison with other commodities" (Fiori, 2003, p. 54). All this contributes to create the image to spread, the image to sell, the image to distinguish itself from the other ones and to compete "promoting idealised and symbolic representations of 'cultural landscapes', in this way the rural becomes a merchandise as physical space, but also as anthropic space, characterized by spiritual resonances, characteristics of romantic simplicity and tradition" (ibid., p. 208).

\section{The local impact of commercial agritourism observing Itria Valley (Apulia Region)}

According to the traditional subregional spatial subdivision (Bissanti, 1991), we can refer to the Murgia of the Trulli (figure 2), whose heart is the Itria Valley. It is characterized by typical white stone buildings as trulli ${ }^{5}$, lamie, cisterns to collect rain and widespread settlements; tabular agrarian structure, mixed and intensive cultivation (olive trees, grape wine, vegetables) developed by little farms for family needs and in some cases for local market (Fiori, Varraso, 2000). In fact, Utilised Agricultural Area (UAA) of the three mains towns of Itria Valley (Cisternino, Locorotondo, Martina Franca), promoting the Itria Valley LAG, is 22.399 hectares and $56 \%$ of this is made by terrains smaller than 5 hectares and, of these ones, 33\% smaller than 2 hectares.

\footnotetext{
${ }^{4}$ The so called rural heritage considers not only the rural community architectonic and artistic expressions and the archaeological evidences, but also the living components that are the local actors with their knowledge and practices, vegetables, soils and all environmental resources (Cevasco, 2005, p. 349).

5 Trulli have been considered "Human Universal Heritage" under the trusteeship of UNESCO.
} 
These percentages are pointed up in the case of Cisternino territory that we have examined. Here the UAA is 4,919 hectares, whose $70 \%$ made by terrains smaller than 5 hectares and, of these ones, 37\% smaller than 2 hectares (GAL Valle d'Itria, 2009).

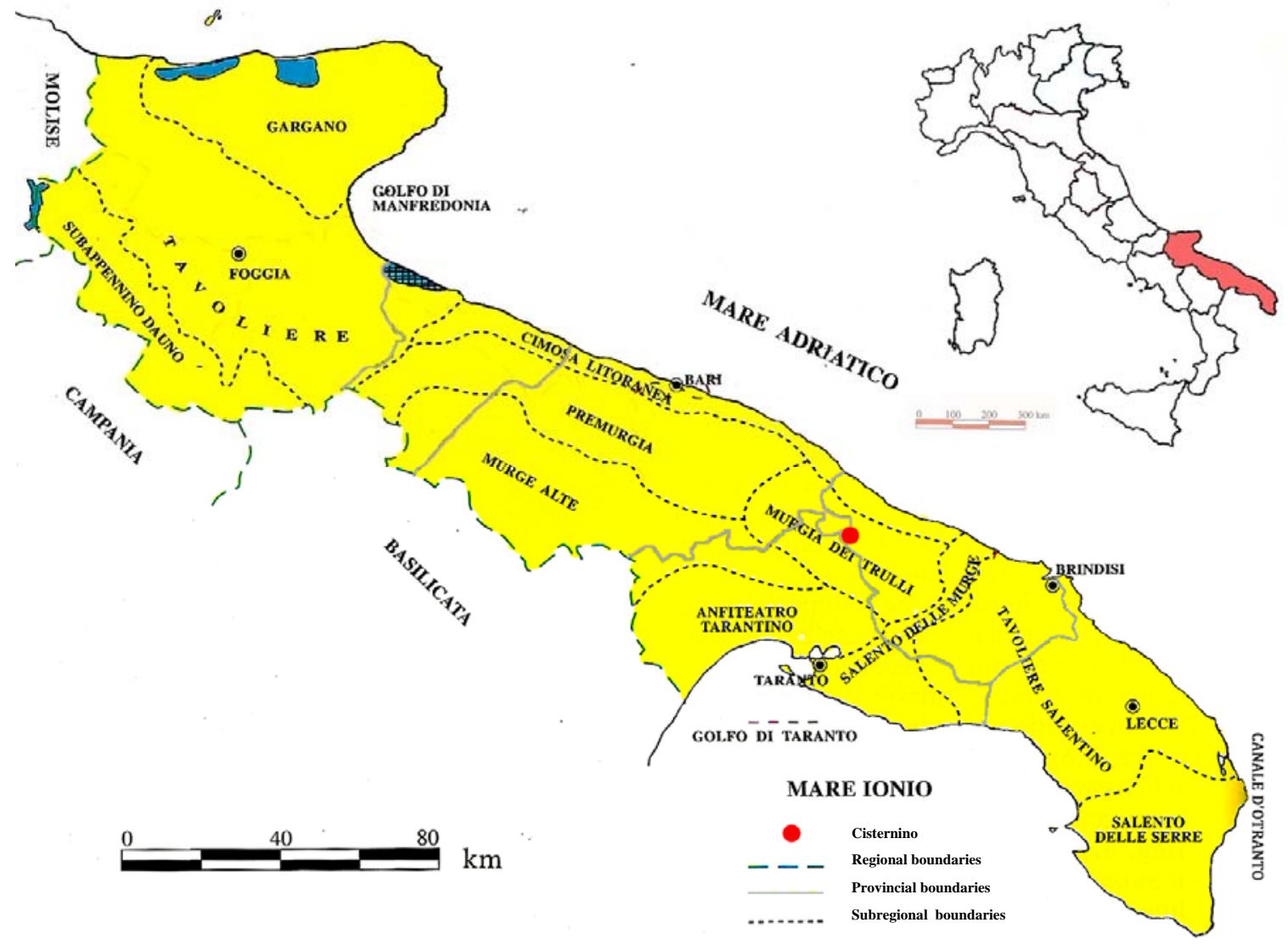

Fig 2. Apulia: traditional subregional spatial subdivision. Source: Bissanti, 1991, p. 12, with update provincial boundaries.

Cisternino is on one highest hill (394 meter) of Apulia Murge, on Itria Valley, $12 \mathrm{~km}$ from Adriatic coast. Its territory is characterized by a large spread rural population, whose more than a half $(6,108)$ of resident persons $(12,078)$ lives in rural areas and 3,262 of these in strewn buildings, cultivating for self-consumption (ISTAT, 2001). Its economy is based on agriculture and tourism, born by a solid culinary and handcraft tradition. This settlement and agricultural model assures the social and ecological protection of territory. It is, in fact, well-kept and safe and it has produced along the time a pleasant landscape that today, besides being at the basis of rural tourism development, is an example of educative value (Grillotti Di Giacomo, 1998). As regards the tourism, the main receptive structure is $B \& B$ referring to the units (21 buildings with 133 beds) and hotel referring to the number of beds (340 beds in five buildings). According to the same official data, there is only an agritourism ${ }^{6}$ (GAL Valle d'Itria, 2009). Nevertheless, out of institutional channels and visiting web sites about the so-called "agritourism holiday" (www.agriturismo.it; www.agriturismo-on-line, www.agriturdoc.com), the number of firms increases also if we come in a very muddling situation, where the "agritourism" term is used also to indicate manor farms and B\&Bs. These structures, near Cisternino, are used in order to individuate the typologies of services offered (table 3 ) and the possible local impact on natural resources and landscape (table 4).

Agritourism's proposals, on the one hand, refer to a solid identity trough a recurring and sometimes emphatic evocation to the typicality accommodation

"we don't offer only a bedroom, but a full of emotion. Not only, you will sleep in one of the rooms built by natural materials, as wood, stone..."

\footnotetext{
${ }^{6}$ In Apulia, the authorised agritourism firms are 357, whose 201 with other activities: 55 horses riding; 19 touring; six natural watching; 71 trekking; 94 mountain bike; 45 courses; 19 sport; 88 various, 11 didactic farms (ISTAT, 2010).
} 


\section{(www.riposodelvento.it)}

"the holiday in a luxury and unusual place offers a rich emotion atmosphere, conciliating the spirit pleasure with mind and body relax" (www.relaisdelduca.com)

and a continuous reference to the territorial features as "buildings in local stone with historical value"; on the other hand, they refer to the modern services (table 3) that evoke urban culture's typical values as comfort, relax, entertainment, privacy. So, Trulli becomes one of the main attractive elements of location, while the organization of the space (inside and outside) and services is not substantial different from that in any other hotel, as well as the international opening level ${ }^{7}$.

\begin{tabular}{|c|c|c|c|c|}
\hline Base services & Comfort services & $\begin{array}{l}\text { Entertainment } \\
\text { and relax } \\
\text { services }\end{array}$ & $\begin{array}{l}\text { Courses and } \\
\text { activities }\end{array}$ & $\begin{array}{l}\text { Services for } \\
\text { privacy }\end{array}$ \\
\hline $\begin{array}{l}\text { - Mobile phone } \\
\text { web } \\
\text { - POS machine } \\
\text { - Mosquito net } \\
\text { - TV } \\
\text { - DVD player } \\
\text { - Internet access } \\
\text { - Wash machine } \\
\text { - Covered parking } \\
\text { - Daily cleaning } \\
\text { of the room } \\
\text { - Daily change of } \\
\text { towels and linen }\end{array}$ & $\begin{array}{l}\text { - Private bathroom } \\
\text { - Fridge bar in the } \\
\text { room } \\
\text { - Private well } \\
\text { equipped kitchen } \\
\text { - Air conditioning } \\
\text { - Central heating } \\
\text { - Hairdryer } \\
\text { - Telephone } \\
\text { - TV in the room } \\
\text { - Free Wi-Fi zone } \\
\text { - Cook } \\
\text { housekeeper } \\
\text { - Baby sitter } \\
\text { service }\end{array}$ & $\begin{array}{l}\text { - Traditional } \\
\text { swimming pool and } \\
\text { with variants (warm } \\
\text { water; salt water; } \\
\text { with play of lights; } \\
\text { with sunbeds, } \\
\text { umbrellas, hot } \\
\text { showers, changing } \\
\text { rooms; paved area } \\
\text { and lawn; pool } \\
\text { attendant) } \\
\text { - Whirlpool bath } \\
\text { - Solarium square } \\
\text { - Gazebo bar } \\
\text { - Gym } \\
\text { - Tennis field } \\
\text { - Football field } \\
\text { - Golf field } \\
\text { - Riding stables } \\
\text { - Recreation ground }\end{array}$ & $\begin{array}{l}\text { - Horseback riding } \\
\text { courses } \\
\text { - Craftsmanship } \\
\text { courses } \\
\text { - Painting courses } \\
\text { - Photography } \\
\text { courses } \\
\text { - Herbs use courses } \\
\text { - Tourist guides } \\
\text { - Excursions }\end{array}$ & $\begin{array}{l}\text { - Private suits } \\
\text { - External spaces } \\
\text { to private use } \\
\text { - External private } \\
\text { space }\end{array}$ \\
\hline
\end{tabular}

Tab 3. Services offered by commercial agritourism near Cisternino according to the examined web sites.

Source: own table on data by www.riposodelvento.it; www.masseriagianca.com: www.relaisdelduca.com; www.masseriaselvaggi.com; www.masseriacappuccini.it; www.masseriamadonnadellarco.it; www.masseriapozzotrepile.com; www.masserialosperone.it; www.masseriasalamina.it.

\begin{tabular}{|r|c|c|c|c|c|c|c|c|c|}
\hline \multirow{2}{*}{ Resources } & \multicolumn{9}{|c|}{ Services offered by commercial agritourism } \\
\cline { 2 - 10 } & $\begin{array}{r}\text { Swimming } \\
\text { pool }\end{array}$ & $\begin{array}{c}\text { Air } \\
\text { conditioning }\end{array}$ & $\begin{array}{c}\text { TV and other } \\
\text { appliance for } \\
\text { private use }\end{array}$ & $\begin{array}{c}\text { Gazebo } \\
\text { bar }\end{array}$ & $\begin{array}{c}\text { External } \\
\text { whirlpool bath }\end{array}$ & $\begin{array}{c}\text { Tennis } \\
\text { field }\end{array}$ & $\begin{array}{c}\text { Football } \\
\text { field }\end{array}$ & $\begin{array}{c}\text { Golf } \\
\text { field }\end{array}$ & $\begin{array}{c}\text { Recreation } \\
\text { ground }\end{array}$ \\
\hline Water & $\mathrm{X}$ & & & & $\mathrm{X}$ & & & $\mathrm{X}$ & \\
\hline Air & & $\mathrm{X}$ & & & $\mathrm{X}$ & & & & \\
\hline Ground & $\mathrm{X}$ & & & $\mathrm{X}$ & $\mathrm{X}$ & $\mathrm{X}$ & $\mathrm{X}$ & $\mathrm{X}$ & $\mathrm{X}$ \\
\hline Energy & $\mathrm{X}$ & $\mathrm{X}$ & $\mathrm{X}$ & & $\mathrm{X}$ & & & & \\
\hline Landscape & $\mathrm{X}$ & & & $\mathrm{X}$ & $\mathrm{X}$ & $\mathrm{X}$ & $\mathrm{X}$ & $\mathrm{X}$ & $\mathrm{X}$ \\
\hline
\end{tabular}

Tab 4. Some services offered by commercial agritourism and their local impact on natural resources and landscape. Source: own table.

Besides comfort, relax and entertainment demand, we find also the demand of authenticity (ISMEA, MPAAF, 2011c). This last, according to an investigation by Agritourism National Observatory (2010, pp. 19-20), is essentially satisfied by location (firm in green and nature, rustic buildings consistent with the external setting), culinary offer (local and natural food products, food cooked by farmers) and organised activities (touring). Only in some cases, authenticity's demand is associated with

\footnotetext{
${ }^{7}$ About nine web sites examined, six are traduced at least in a foreign language and precisely: two in English; two in English and German; one in English, German and French, one in English, German, French, Romanian and Japanese.
} 
an agricultural activity "if possible with animals" and, in some case, with the possibility to participate in the farm life. As regards agricultural activity, in the most part of the cases considered, there is not an explicit reference to this one, except to invite to buy some products, to a bike walk in "a garden with secular olive trees" or to taste season fruits from "each kind of trees". And even when there is a reference to the cultivation, there is not the smallest mention to the possibility to participate in agricultural activities. The same happens for production of cheeses and compotes. The unique invitation is to the degustation.

The choice to adapt agritourist activity to the market demand means take "urban lifestyle in a rural location - modern services in a tradition place". This represents a threat to the authenticity of local culture. That is the "capacity of people and communities to create difference, and to resist thus to the capitalism logic that pushes towards the homologation" (Fiori, 2003, p. 54). In the same time, the use of elements and words as "traditional, typical, identity" to promote places, goods and services, produce the stage authenticity to attract tourists.
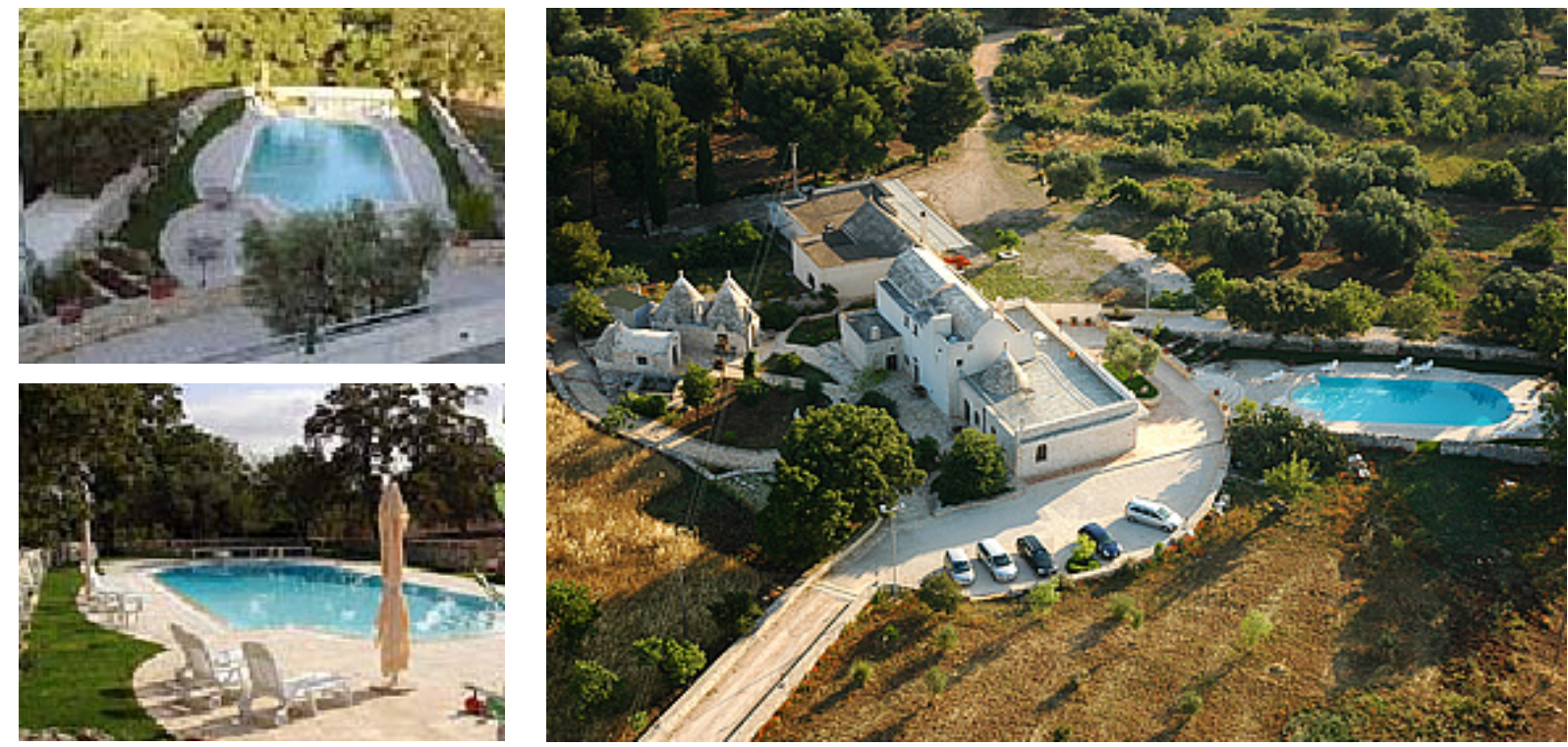

Fig 3. "Masseria Selvaggi" agritourism: grass lawn and swimming pool in an olive trees' field. Photos by www.masseriaselvaggi.com.

Commercial agritourism, disconnected from an authentic rural lifestyle (figure 3), produces environmental stress, as in the case of other types of tourism and a landscape impact possibly bigger because of natural level of place. This type of agritourism can produce a remarkable impact also on territorial socio-economic organization, and it influences further agriculture's marginalization, through:

a) farmer's "transformation" in a business man with the consequent loss of competences and capacity to transmit them to the future generations;

b) change of land's use and removal of the ground to the agricultural use;

c) urbanization of rural lifestyle and consequent cultural homologation.

All this produces a deconstruction of traditional relations and contributes to damage also the role of rural zones. Consequently, the task of little towns as places that "can contribute to protect those significantly lifestyles, for abundance of traditions, costumes and memories, seriously attempted from progressive advancement of globalization processes that standardize and uniform products with places and behaviour" (Varraso, 2007, p. 242).

\section{The organic firm "Raggio Verde" and its ecological agritourism project}

The "Raggio Verde" organic agricultural firm is localized in Cisternino (Brindisi) at about $2 \mathrm{~km}$ from the historical centre. It has a surface of 6 hectares, including 5 hectares of olives grove. Olives are used to produce organic olive oil, pressed with mechanical instruments. The olive oil is sold on 
the international, national and local market: $70 \%$ in Switzerland and Germany, 25\%, in the North of Italy. Markets have been created by personal contacts and relations of farmer aided by word of mouth, without professional brokers. On international markets, olive oil is sold with a double price as to that of local market, and this allows supporting initiatives aimed at biodiversity preservation and environmental protection. In this case, in fact, the olive oil price includes a part explicitly finalised to these activities. So, the relation between producer and customer is over the commercial exchange, regarding also common values and planning. For instance, customers who buy at least 180/200 litres of olive oil each year during three years, have the chance to spend a week in the farm with free board and lodging, in order to acknowledge about ecological conservation project. The firm is conducted by owner and his family. The vision of the firm is based on idea that the work is a way to care environment, protect ecologic balance and spread ecologic culture. At this aim, different hypothesis of multifunctional opening have been examined, and it has been identified as possible the production of public goods and rural tourism. As regards this last, an organic ecological agritourism project, joined with an environmental impact reduction plan, has been drawn up.

The choice has been adopted according to firm analysis and SWOT analysis referring to: a) the double function of agricultural firms established by EU law 834/2007 (maker of market goods and public goods); b) two macro classes of aims (for firm and territory). The SWOT analysis, among other things, has highlighted the coincidence between firm "development" and territorial "development", as everything, which represents strengths or weaknesses, opportunities or threats for the territory, it is the same for the firm, and vice versa. This shows the strong territorial nature of the firm. According to an interdependent process, the firm depends strictly on the place for its activity and this activity contributes to the development of the area.

The strategies to apply have been substantially individuated thanks to:

a) internal strength factors both of firm and territory, about environment and landscape (as the presence of trulli, low dry-stone walls, well-kept countryside, woods);

b) opportunities offered by external conditions. This last refers, on the one hand, to the EU Rural Development Program 2007-2013 and the related funding (Axis III, Measure 311), on the other hand, to the increasing demand for rural, naturalistic and cultural tourism.

\subsection{A new typology of agritourism: the "open agritourism"}

The purposes of this project concern socio-economic, environmental, socio-cultural and landscape spheres: revenue's increasing, traditional activities' safeguard and spreading; biodiversity's preservation; approaching citizens to know countryside and its natural cycles, education to rural life, spreading of ecologically consistent models and lifestyles; traditional buildings' maintenance. The project is based on an ideal matrix that can be summarized by following key words: relation and responsibility. First the capacity to connect people and to create links among people and the nature. Secondly the capacity to find solutions concerning environmental issue. From this point of view, the "Raggio Verde" firm makes its offer not in an undifferentiated way to anonymous costumers anxious for buy/consume/possess, but in a focused way to people interested in living a really authentic rural and human experience, longing for knowledge of a simple lifestyle.

The project is composed of two options. The first one is based on the hospitality offer (free board and lodging) in exchange for the participation to the olive crop. This option has been proposed also because of the additional labour during olive harvesting and in order to reduce production cost. Moreover, this option can facilitate people presence during all the year. The second one considers the participation of guests in direct and indirect learning activities concerning rural world, typical cooking and handcraft laboratory. It plans exploratory, theoretic and practice learning's activities, which are organised according to four methods: explorative, participative, communicative and manual (table 5). This option is offered from April to September, for a weekend or longer periods. 


\begin{tabular}{|c|c|c|c|}
\hline \multicolumn{4}{|c|}{ Learning by } \\
\hline exploration & participation & word & doing \\
\hline $\begin{array}{l}\text { Rural itineraries in order to: } \\
\text { know fauna, flora and } \\
\text { autochthon fruits; } \\
\text { recognition, collect and } \\
\text { guide to use of herbs and } \\
\text { curative plants. } \\
\text { Natural itineraries in: } \\
\text { Itria Valley, woods, sea. } \\
\text { Visits (also for didactics } \\
\text { goals) to: crusher, } \\
\text { traditional firms and } \\
\text { organic farms, historical } \\
\text { centre, "Bhole Baba" } \\
\text { Ashram's centre. }\end{array}$ & $\begin{array}{l}\text { Agricultural production: } \\
\text { planting, pruning, crop. } \\
\text { Care of soil's and plant's } \\
\text { health: canopy seeding, } \\
\text { green manure, grassing. } \\
\text { Compost production } \\
\text { Hydrogeological control: } \\
\text { terrace maintenance. } \\
\text { Biodiversity: search of } \\
\text { autochthon flora and fauna, } \\
\text { restoration of micro fauna } \\
\text { habitat. }\end{array}$ & $\begin{array}{l}\text { Cultural and formative } \\
\text { meeting about following } \\
\text { issues: } \\
\text { ecological management } \\
\text { of natural resources; } \\
\text { organic agriculture; } \\
\text { traditional food; } \\
\text { natural remedies. }\end{array}$ & $\begin{array}{l}\text { Handcraft lab concerning } \\
\text { building and handing of } \\
\text { low dry-stone walls; } \\
\text { manufacturing wood } \\
\text { handcraft products; } \\
\text { jam and compote } \\
\text { production; bread and } \\
\text { dairy products; traditional } \\
\text { and natural cooking. }\end{array}$ \\
\hline
\end{tabular}

Tab 5. Theoretic and practice learning activities, organised by different learning methods. Source: own table.

Referring to framework of agritourism typology defined by Philip and other (figure 1), the project can be classified as "working farm, direct contact". Specifically, the first option can be undoubtedly related to the subcategory called "authentic agritourism" because it is based on authentic experiences of agriculture and tourist's participation in the farm task. The second option could be related to the subcategory called "staged agritourism" only referring to some activities organised purposefully for tourist (as rural and natural itineraries, cultural and education meeting, handcraft laboratories) but in contrast with this model, agricultural activities are not staged.

In fact, in the case of "Raggio Verde" firm, tourists experience agricultural activities that have not been put on purposefully (or staged) for tourism, as in the case of "staged agritourism" typology, but they experience authentic agricultural activities. In addition:

a) the firm is not arranged to attract tourists;

b) the firm is not decorated to appear as back region and any setting is reproduced;

c) there is not any farming demonstration;

d) anything is organised to "overcome hazards implicit to an otherwise authentic working farm environment" (Philip and other, 2010, p. 757);

e) the tourist is a guest, not a customer and, consequently, her/he is not a consumer and/or a passive viewer but a traveller invited to observe, to listen, to smell, to taste, to touch the rural culture, to explore the rural world, to know and make experience until to participate to the rural life.

So, in this case, it seems correct to identify a new category that, referring to the authentic agricultural activity, makes explicitly reference to the main purpose of "Raggio Verde" proposal (that is to open the doors of rural world to the citizens) and tourist's intention (that is to know and learn about rural culture). So, we propose to introduce a new agritourism typology in the framework defined by Philip and others (figure 1), that we label "open agritourism" and that is based on the main tourist's purpose for experiencing authentic agricultural activities: knowledge rural values and lifestyle, learning agricultural and handcraft activities (figure 4). 


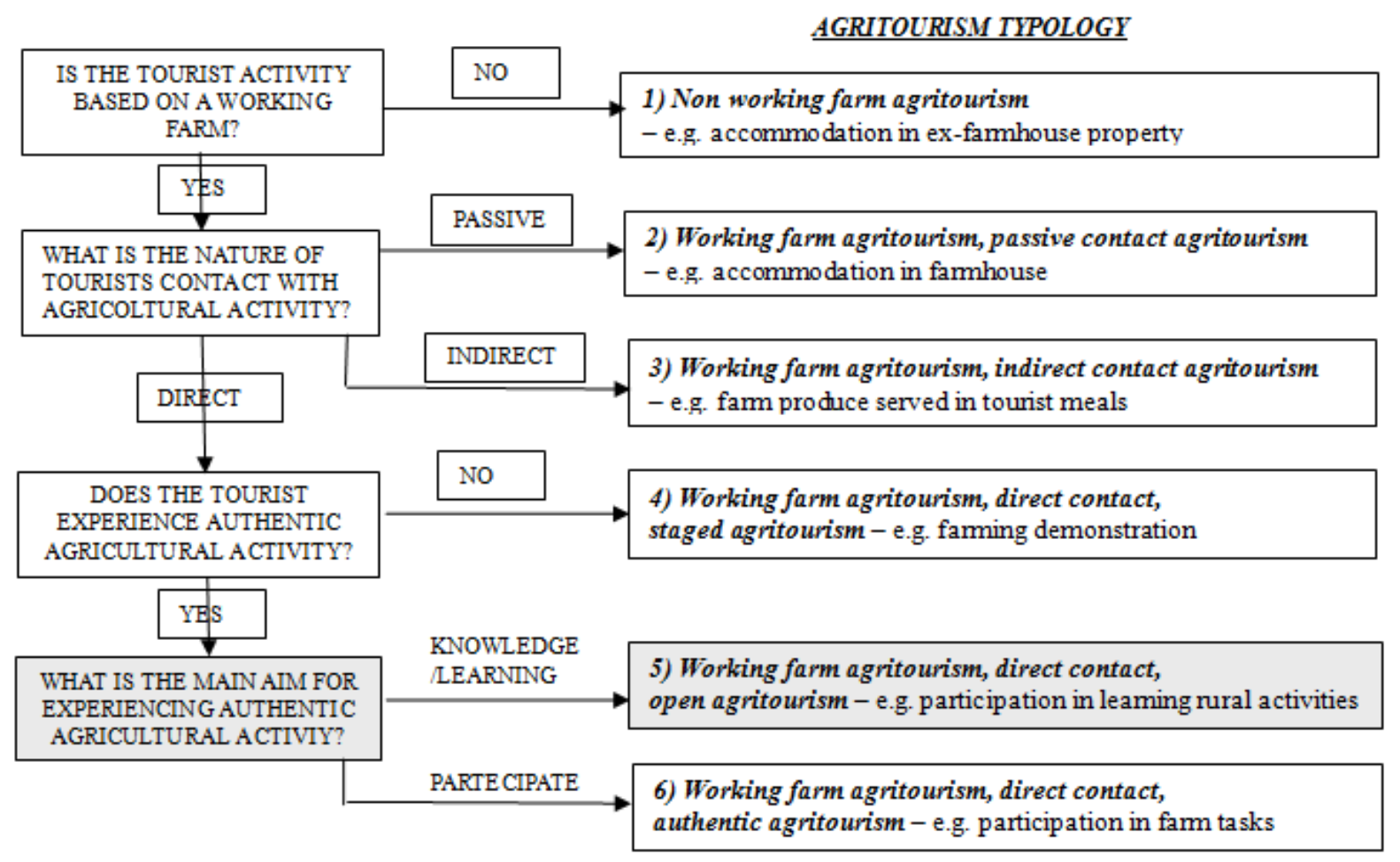

Fig 4. A new typology for defining agritourism. Source: adapted upon Philip and others (2010, p. 756).

\subsection{The project toward a "zero environmental impact agritourism"}

Agritourist activity on one side needs new equipped spaces, on the other side implies an increasing of water and energy use, in addition to wastes' production. For this reason, a project of restoration of traditional buildings (three groups of trulli located on firm soil) considering the EU funding (PSR 2007-2013) and a resources' management plan to reduce the environmental impact (referring to agricultural activity too) have been arranged. The project adopts as ideal model the "zero environmental impact and closed-loop", are internal and wastes produced are reused as, if possible, an input of other productive processes (figure 5).

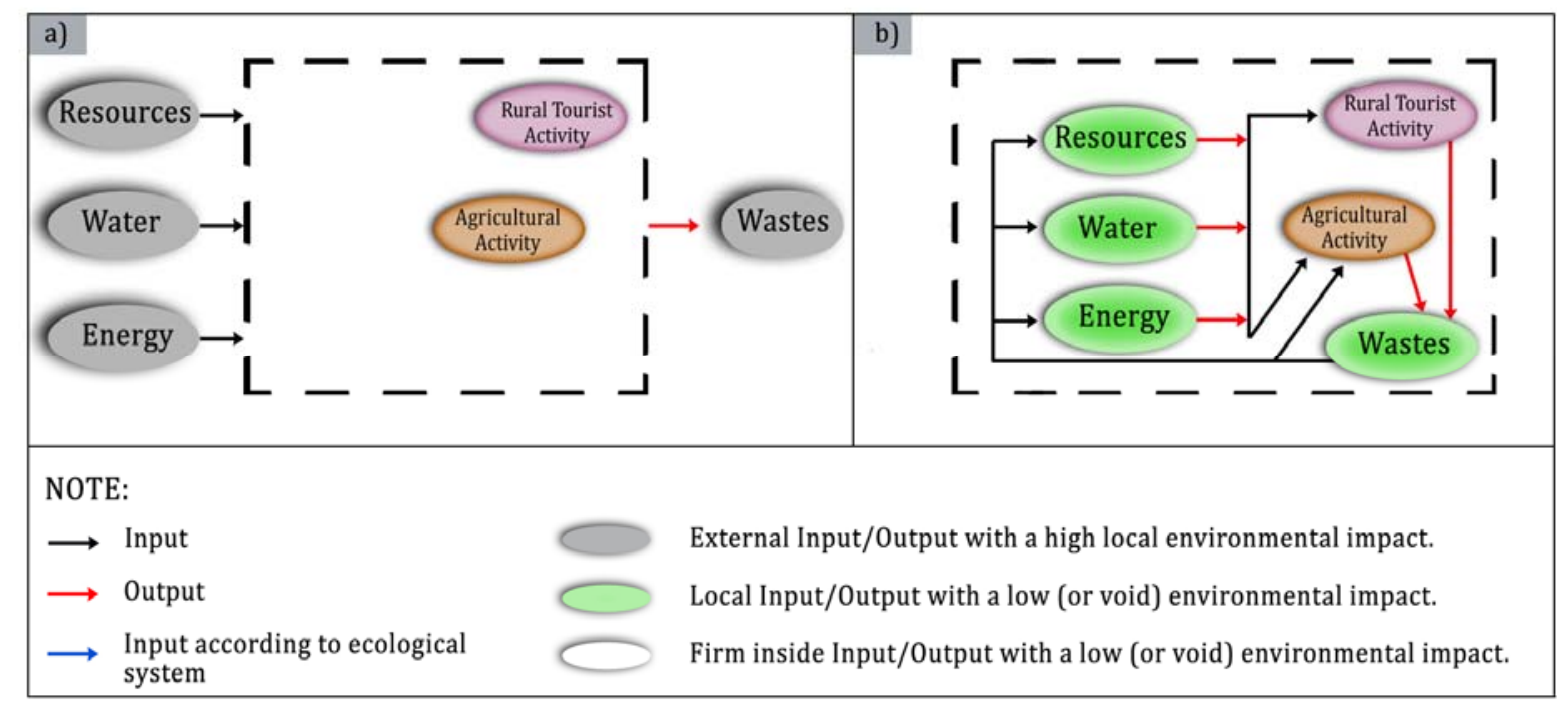

Fig 5. High ecological impact system (a); zero environmental impact and closed-loop theoretic system (b). Source: own figure.

\footnotetext{
${ }^{8}$ In Italy, there are some cases of "zero impact" agritourism (http://colleregnano.it) and others-ones that adopt policies to reduce the ecological impact (www.premioinnovazione.legambiente.org).
} 
In the "Raggio Verde" firm, the productive factors are gotten on local scale and agriculture is organic. This is the reason of a very low ecologic impact and a virtuous environmental interaction. We can add a set of other ecologic practices achieved: rain collection in the cistern for irrigation, thermo fireplaces with biofuel for heating (by wood, dry biomass, waste materials from pruning and other agricultural works). However, the margins to improve are still several. For instance, the biomass produced by the firm is not sufficient for needs, and for this reason, the firm buys it or uses gas stoves. Energy for both lighting and warm water is produced by non-renewable fuels. It is the same for fuel used for work machinery (gas oil) and for commercial and private transport (petrol). Furthermore, the fresh water supply, bought from the cistern truck, has an important ecological (beyond economic) weight, so as the sewage is not recovered. Thus, a plan to reduce the environmental impact has been prepared. It focuses on input supply for productive activities and on output management resulting from them. In this perspective, it needs to make a choice on the base of a global firm activity's vision (figure 6), starting with the assumption that a less inside organizational complexity corresponds to a major ecological impact (t1), while an increasing of inside organizational complexity coincides with a lower environmental impact (t2).

The idea is to reduce the consumptions and the dependence from external sources, to maximize the renewable energies' and produced wastes' use, cutting at the same time the energy and materials that come out. Of course, these initiatives, besides the ecological impact decreasing, in a middle and long time, would produce an economic save too. The activities to reduce the environmental impact concerns water, energy and wastes (table 6).

\begin{tabular}{|l|l|l|l|l|l|}
\hline \multicolumn{2}{|c|}{ Water } & \multicolumn{2}{c|}{ Energy } & \multicolumn{2}{c|}{ Wastes } \\
\hline $\begin{array}{l}\text { Reduction of } \\
\text { consumption }\end{array}$ & $\begin{array}{l}\text { Provisioning of } \\
\text { resource }\end{array}$ & \multicolumn{1}{c|}{$\begin{array}{c}\text { Reduction of } \\
\text { consumption }\end{array}$} & $\begin{array}{l}\text { Provisioning of } \\
\text { resource }\end{array}$ & $\begin{array}{l}\text { Reduction of } \\
\text { consumption }\end{array}$ & Resource recovery \\
\hline $\begin{array}{l}\text { Shower and } \\
\text { faucet flow } \\
\text { adapters. }\end{array}$ & $\begin{array}{l}\text { Rainwater } \\
\text { collection } \\
\text { (cisterns). }\end{array}$ & $\begin{array}{l}\text { Energy saving light } \\
\text { bulbs and } \\
\text { appliances. }\end{array}$ & Solar panels. & $\begin{array}{l}\text { Reduction of } \\
\text { packaging. }\end{array}$ & $\begin{array}{l}\text { Organic waste for } \\
\text { compost (enlarge } \\
\text { stock's space). }\end{array}$ \\
\hline $\begin{array}{l}\text { Installations for } \\
\text { black water } \\
\text { recovery. }\end{array}$ & $\begin{array}{l}\text { Black water herbal } \\
\text { purification for } \\
\text { agricultural use }\end{array}$ & $\begin{array}{l}\text { Thermal insulation } \\
\text { of walls. }\end{array}$ & $\begin{array}{l}\text { Cut-off of } \\
\text { disposable products }\end{array}$ & $\begin{array}{l}\text { Agricultural residues } \\
\text { and cardboard for } \\
\text { thermo fireplace. }\end{array}$ \\
\hline & & $\begin{array}{l}\text { Double glazing } \\
\text { installation. }\end{array}$ & & $\begin{array}{l}\text { Use of detergents } \\
\text { with recharge. }\end{array}$ & $\begin{array}{l}\text { Glass for jams and } \\
\text { compotes. }\end{array}$ \\
\hline
\end{tabular}

Tab 6. "Raggio Verde" firm plan for local environmental impact reduction. Source: own table. 


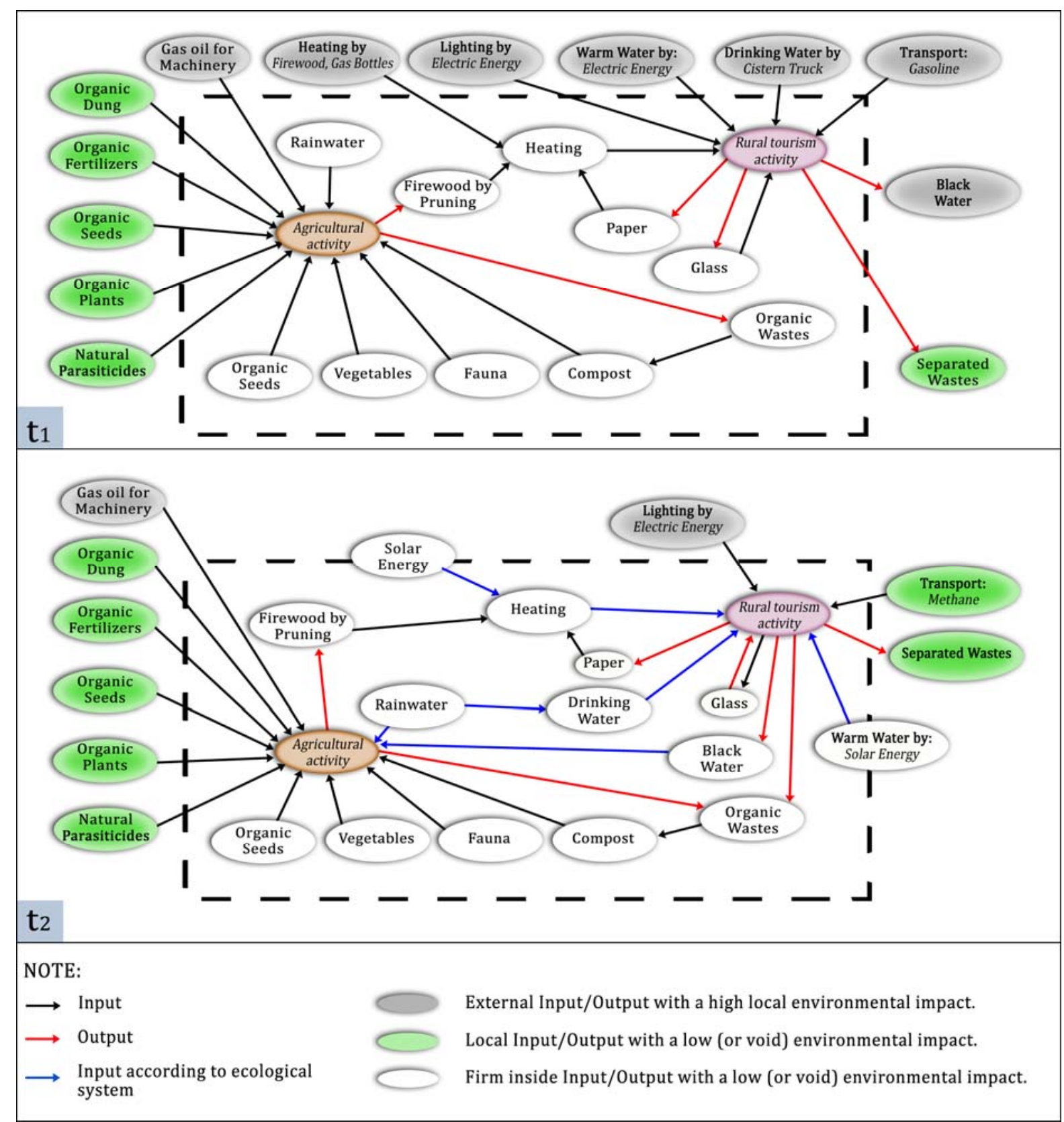

Fig 6. "Raggio Verde" firm ecosystem: input and output management at the present (t1) and in the future (t2) with the aim to reduce the local ecological impact. Source: own figure.

\section{Conclusions and suggestions for further researches}

The agritourism, born as an activity linked with the agricultural and rural world, is strictly interdependent from territorial and cultural heritage, and it can preserve or destroy them. The local impact of agritourism basically depends on the offered services' ecological weight. These services, on their turn, depend on their own cultural and value matrix. It affects the kind of relation population-resources (according to ecosystem balance or to the market's liberal system), on the objectives and the short/middle/long time horizon to reach them.

The genuine agritourism is characterized by tight agricultural connection as its name says, local culture, rural lifestyles and, especially, the coincidence between economic and territorial "interests". It could be a mean to resist the standardization's power of global market and to offer an alternative to the "cow-boy" exploitation's economy, to the commodification's culture and, thus, to the homologation of places and behaviour. However, if rural traditions and cultural heritage are used mainly as an attractive factor to compete in the market according to its rules and for its aims, agritourism can produce a high territorial impact and also gradually spoil or destroy the soul of place. In fact, the commercial agritourism, that has as main purpose 
the revenues' increasing in short-middle term by competitiveness, would realise only firm policies coherent with its own aim even if these could cause socio-cultural, landscape and environmental costs. Moreover, production costs' externalization is the result of market dynamic and a stop to it could derive only from the entrepreneur's consciousness that some choices can damage its own business' basis as the landscape, or by prohibitions imposed by law to safeguard the general interest. The commercial agritourism, losing its bonds with agriculture, seems doomed in the middle/long time to failure its main goals to support the rural world that is used as a mere productive factor. At the same time, it seems destined to damage the elements necessary for its own life (because of resources' impoverishment, pollution, agricultural marginalization, edification and transformation of landscape) and, on a larger scale, the ecological balance. Finally, to evaluate the agritourism's local impact it is crucial to evaluate its relations to environment and society, its dependence's level from external sources and its ecosystem "weight", according to energy, water and material source and quantity.

As regards specifically agritourism in Italy, the most recent national laws (according to EU planning) stimulate commercial agritourism with an offer of comfort solutions, more and more differentiated modern services and the offer of various activities. At the same time, the connection with agriculture becomes weaker. From this point of view, we are watching the commodification of rural world, landscapes, traditions and territorial identity. These elements are used in promotional messages, but they appear less central in business choices. This fact should encourage a discussion about, on one side, agritourism model, rural development and the real goals of powers which influence this development; on the other side, the urbanization process of rural lifestyle and, thus, cultural homologation. It should also stimulate reasoning about the moral implications because, to use the words of Fiori (2003, p. 13), "to contribute to understand and to use the identity request for economic and utilitarian aims, can mean to contribute as well to the people's and territories' exploitation".

The "Raggio Verde" firm ecological agritourism project that we illustrated throughout this work didn't start yet because of, basically, EU Rural Development (2007-2013) Program funding criterion (Axis III - Measure 311 - Action 1) that, establishing 50\% aid as capital expenditure, weakened one of the main external environment's opportunities detected by SWOT analysis and at the basis of the project. Effectively, the choice to limit the founding to $50 \%$, blocking the access to the EU funds, penalises the little agricultural firm which, in Italy, generally has not an important capital nor can easily have access to the credit. At the same time, this choice benefits who has a capital or, at least, who has a major possibility to have access to the credit, as the big and middle firms. It is just the case to underline that the impossibility for the "Raggio Verde" firm to benefit of this funding has, de facto, vanished the previous EU funding, POR Puglia 2000/2006 (that has sustained the action-research, as you can see in the second footnote), aimed at supporting the little firm to develop its own economic and territorial potential.

As in the case of other studies (Gossling, 2003), the same basic demand remains: "development for whom, for what purpose, to what end?". In this case, perhaps, some answers could come from an analysis on different levels of spatial scale. On the local scale, referring to Itria Valley, a research about origin and last work of agritourist operators, with the data about activity's beginning (start-up year, borrowers of potential funding, etc.), would identify the reason of agritourist spreading. It could be due to a business investment choice, rather than a real agricultural income's diversification choice. On the regional scale, referring to Apulia, a research concerning the actors which have benefited from FSR 2007-2013 funding (farmers? citizens? natives? persons? societies?) could be interesting. These data could confute or confirm the hypothesis that EU (with the endorsement of States and Regions) supports a rural world's representation to advantage the wealthy groups, which have greater possibility to invest and, so, to use a part of public funds for their business or personal interests, or to satisfy the "urban-postmodern" desire to recover traditions, identity and root. This research extended to the results of the same rural development programs in other territories and, possibly, also on the national scale, could finally indicate if this hypothesis of the relation between EU funding and regional planning is, eventually, due to the resources' management from a particular administration, or if it is an unavoidable effect deriving from mechanism directed at it. 


\section{Acknowledgement}

This research has been presented in the International Agritourism Smart Conference "Agritourism between embeddedness and internationalization", on 14-16 June 2012 in Slovenia, organised by the Universities of Liege and Ljubljana, on the base of cooperation agreement, which binds the Wallonia-Brussels Federation and Slovenia.

The project is part of a research sponsored by European Union with the partnership of Department of Commodity and Geographic Science - University of Bari, through a regional program (POR Puglia 2000/2006) to support the little firms in developing their territorial and economic potential. The research has been developed from January 2007 to June 2008.

\section{References}

[1] Agritourism National Observatory (2010). Analisi della domanda, dell'offerta, e dei servizi di agriturismo, Roma. Ministerio delle politiche agricole, alimentare e forestale.

[2] Bachleitner, R. \& Zins, A. (1999). Cultural tourism in rural communities: the residents' perspective, Journal of Business Research, 44(3), 199-209. Doi: 10.1016/S01482963(97)00201-4.

[3] Bissanti, A. A. (1991). Puglia. Geografia attiva, Bari: Adda Editore.

[4] Cawley, M. \& Gillmor, D. (2008). Integrated rural tourism: concepts and practice. Annals of Tourism Research, 35(2), 316-337. Doi: 10.1016/j.annals.2007.07.011.

[5] Centner, T. J. (2010). New state liability exceptions for agritourism activities and the use of liability releases. Agriculture and Human Values 27(2), 189-198. Doi: 10.1007/s10460-0099220-y.

[6] Cevasco, R. (2005). Nuove risorse per la geografia del turismo rurale. Ecologia storica e risorse ambientali nell'Appennino ligure/emiliano. Bollettino della Società Geografica Italiana 10(2), 340-355.

[7] Chhabra, D., Healy, R. \& Sills, E. (2003). Staged authenticity and heritage tourism. Annals of Tourism Research 30(3), 702-719. Doi: 10.1016/S0160-7383(03)00044-6.

[8] Cohen, E. (1988). Authenticity and Commoditisation in Tourism. Annals of Tourism Research 15(3), 371-386. Doi: 10.1016/0160-7383(88)90028-X.

[9] Conti, S. (1996). Geografia economica, Torino: Utet.

[10] Crang, P. (1997). Performing the Tourist Product. In Rojek, C. \& Urry, J., eds., Touring Cultures: Transformations of Travel and Theory (pp. 137-154). London: Routledge.

[11] Daniel, Y. P. (1996). Tourism Dance Performances: Authenticity and Creativity. Annals of Tourism Research 23(4), 780-797. Doi: 10.1016/0160-7383(96)00020-5.

[12] Daugstad, K. (2008). Negotiating landscape in rural tourism. Annals of Tourism Research 35(2), 402-426. Doi: 10.1016/j.annals.2007.10.001.

[13] Dubois, C. \& Schmitz, S. (2010). Which Countryside for which Agritourism? A comparative Analysis. In Amit-Cohen, I., ed., Sustainability in Transition and the Changing Faces of Rural Areas: Environmental, Social, Cultural and Economic Dimensions. Ramat Gan: Bar Ilan University.

[14] Dubois, C. \& Schmitz, S. (2011). The way to agritourist development from constraints to opportunities. In Cawley, M., ed., The Sustainability of Rural Systems: Local and Global Challenges and Opportunities (pp. 34-35). Galway: National University of Ireland.

[15] Edensor, T. (2000). Staging tourism. Tourists as Performers. Annals of Tourism Research 27(2), 322-344. Doi: 10.1016/S0160-7383(99)00082-1. 
[16] Fiori, M. \& Varraso, I. (2000). Tavola "Puglia" e tavola "Murgia dei Trulli". In Grillotti di Giacomo, M. G., ed., Atlante tematico dell'agricoltura italiana (pp. 345-350; 387-388). Roma: Società Geografica Italiana.

[17] Fiori, M. (2003). Identità territoriale per lo sviluppo e l'imprenditorialità. Applicazioni geoconomiche d'una metodologia quali-quantitativa. Bari: WIP Edizioni Scientifiche.

[18] GAL Valle d'Itria (2009). Piano di Sviluppo Locale.

[19] Goffman, E. (1959). The Presentation of Self in Everyday Life New York: Doubleday \& Co. Inc.

[20] Gossling, S. (2003). Market integration and ecosystem degradation: Is sustainable tourism development in rural communities a contradiction in terms? Environment, Development and Sustainability 5(3-4), 383-400. Doi: 10.1023/A:1025777029741.

[21] Grillotti di Giacomo, M. G. (1998). I valori dell'agricoltura nel tempo e nello spazio. Genova: Brigati.

[22] Halewood, C. \& Hannam, K. (2001). Viking Heritage Tourism: Authenticity and Commodification. Annals of Tourism Research 28(3), 565-580. Doi: 10.1016/S01607383(00)00076-1.

[23] Hillman, W. (2007). Revisiting the concept of (objective) authenticity. Retrieved from www.tasa.org.au/conferences/conferencepapers07/papers/26.pdf.

[24] Hughes, G. (1995). Authenticity in Tourism Annals of Tourism Research 22(4), 781-803. Doi: 10.1016/0160-7383(95)00020-X.

[25] INEA (2010). Indagine sulle tipologie di offerta e sulle motivazioni delle imprese, Roma.

[26] INSART (2009). Il mercato agrituristico nelle rilevazioni dell'Osservatorio Nazionale del Turismo, Roma.

[27] ISMEA, MPAAF (2011a). Analisi della domanda di agriturismo: risultato dello studio del mercato nazionale svolto nel 2010, Roma.

[28] ISMEA, MPAAF (2011b). Osservatorio nazionale dell'agriturismo. Lo studio della domanda di agriturismo svolta nel 2010, Roma.

[29] ISMEA, MPAAF (2011c). Analisi della domanda di agriturismo in alcuni paesi europei, Roma.

[30] ISTAT (2001). Popolazione residente e abitazioni nelle province italiane. Brindisi. XIV Censimento generale della popolazione e delle abitazioni, Roma.

[31] ISTAT (2010). Le aziende agrituristiche in Italia, Roma.

[32] MacCannell, D. (1973). Staged Authenticity: Arrangements of Social Space in Tourist Settings. The American Journal of Sociology. 79(3), 589-603.

[33] MacCannel, D. (1976). The Tourist: A New Theory of the Leisure Class. New York: Schocken Books.

[34] Mkono, M. (2012). An etnographic examination of constructive authenticity in Victoria Falls tourist (restaurant) experiences. International Journal of Hospitality Management. 37(2), 387-394. Doi: 10.1016/j.ijhm.2011.06.013.

[35] Kontogeorgopoulos, N. (2004). Ecotourism and mass tourism in Southern Thailand: Spatial interdependence, structural connections, and staged authenticity. GeoJournal 61(1), 1-11. Doi: $10.1007 / s 10708-005-8631-6$.

[36] Kuo, N. W. \& Chu, Y. T. (2006). The assessment of agritourism policy based on SEA combination with HIA. Land Use Policy. 23(4), 560-570. Doi: 10.1016/j.landusepol.2005.08.001.

[37] Olsen, K. (2002). Authenticity as a Concept in Tourism Research. Tourist Studies 2(2), 159-182. Doi: 10.1177/146879702761936644. 
[38] Phillip, S., Hunter, C. \& Blackstock, K. (2010). A typology for defining agritourism. Tourism Management. 31(6), 754-758. Doi: 10.1016/j.tourman.2009.08.001.

[39] Resinger, Y. \& Steiner, C. J. (2006). Reconceputalizing object authenticity. Annals of Tourism Research 33(1), 65-86. Doi: 10.1016/j.annals.2005.04.003.

[40] Sanagustin, M. V., Mosene, J. A., \& Gòmez y Patino, M. (2011). Rural tourism: a sustainable alternative. Applied Energy 88(2), 551-557. Doi: 10.1016/j.apenergy.2010.08.031.

[41] Sedmak, G. \& Mihalic, T. (2008). Authenticity in mature seaside resorts. Annals of Tourism Research. 35(4), 1007-1031. Doi: 10.1016/j.annals.2008.07.004.

[42] Sharpley, R. \& Jepson, D. (2011). Rural Tourism. A spiritual experience. Annals of Tourism Research. 38(1), 52-71. Doi: 10.1016/j.annals.2010.05.002.

[43] Taylor, J. (2001). Authenticity and Sincerity in Tourism. Annals of Tourism Research 28(1), 7-26. Doi: 10.1016/S0160-7383(00)00004-9.

[44] Tew, C. \& Barbieri, C. (2012). The perceived benefits of agritourism: The provider's perspective. Tourism Management 33(1), 215-224. Doi: 10.1016/j.tourman.2011.02.005.

[45] Varraso, I. (2007). Piccoli Comuni: realtà marginali che vogliono guardare al futuro. In Onesti, T., Angiola, N., eds., La Governance dei Piccoli Comuni (pp. 237-263). Milano: Franco Angeli.

[46] Waitt, G. (2000). Consuming Heritage. Perceived Historical Authenticity. Annals of Tourism Research 27(4), 835-862. Doi: 10.1016/S0160-7383(99)00115-2.

[47] Waller, J. \& Lea, S. (1999). Seeking the Real Spain? Authenticity and Motivation. Annals of Tourism Research 26(1), 110-129. Doi: 10.1016/S0160-7383(98)00058-9.

[48] Wang, N. (1999). Rethinking authenticity in tourism experience, in Annals of Tourism Research 26(2), 349-370. Doi: 10.1016/S0160-7383(98)00103-0.

[49] Zue, Y. (2012). Performing heritage: rethinking authenticity in tourism. Annals of Tourism Research 39(3), 1495-1513. Doi: 10.1016/j.annals.2012.04.003. 